\title{
Development of a real-time multiplex PCR assay for the detection of multiple Salmonella serotypes in chicken samples Edel O'Regan ${ }^{1}$, Evonne McCabe ${ }^{2}$, Catherine Burgess ${ }^{2}$, Sheila McGuinness ${ }^{3}$, Thomas Barry ${ }^{3}$, Geraldine Duffy ${ }^{2}$, Paul Whyte ${ }^{1}$ and Séamus Fanning*1
}

\author{
Address: ${ }^{1}$ Centres for Food Safety and Food-borne Zoonomics, UCD Veterinary Sciences Centre, University College Dublin, Belfield, Dublin 4, \\ Ireland, ${ }^{2}$ Ashtown Food Research Centre, Teagasc, Ashtown, Dublin 15, Ireland and ${ }^{3}$ Department of Microbiology, National University of Ireland \\ Galway, Galway, Ireland \\ Email: Edel O'Regan - edel.oregan@ucd.ie; Evonne McCabe - evonne.mccabe@teagasc.ie; Catherine Burgess - kaye.burgess@teagasc.ie; \\ Sheila McGuinness - s.mcguinness3@nuigalway.ie; Thomas Barry - thomas.barry@nuigalway.ie; Geraldine Duffy - geraldine.duffy@teagasc.ie; \\ Paul Whyte - paul.whyte@ucd.ie; Séamus Fanning* - sfanning@ucd.ie \\ * Corresponding author
}

Published: 21 September 2008

BMC Microbiology 2008, 8:156 doi:10.1186/147|-2180-8-156
Received: 18 April 2008

Accepted: 21 September 2008

This article is available from: http://www.biomedcentral.com/I47/-2/80/8/I56

(C) 2008 O'Regan et al; licensee BioMed Central Ltd.

This is an Open Access article distributed under the terms of the Creative Commons Attribution License (http://creativecommons.org/licenses/by/2.0), which permits unrestricted use, distribution, and reproduction in any medium, provided the original work is properly cited.

\begin{abstract}
Background: A real-time multiplex PCR assay was developed for the detection of multiple Salmonella serotypes in chicken samples. Poultry-associated serotypes detected in the assay include Enteritidis, Gallinarum, Typhimurium, Kentucky and Dublin. The traditional cultural method according to EN ISO 6579:2002 for the detection of Salmonella in food was performed in parallel. The real-time PCR based method comprised a pre-enrichment step in Buffered Peptone Water (BPW) overnight, followed by a shortened selective enrichment in Rappaport Vasilliadis Soya Broth (RVS) for 6 hours and subsequent DNA extraction.
\end{abstract}

Results: The real-time multiplex PCR assay and traditional cultural method showed 100\% inclusivity and 100\% exclusivity on all strains tested. The real-time multiplex PCR assay was as sensitive as the traditional cultural method in detecting Salmonella in artificially contaminated chicken samples and correctly identified the serotype. Artificially contaminated chicken samples resulted in a detection limit of between I and 10 CFU per $25 \mathrm{~g}$ sample for both methods. A total of sixty-three naturally contaminated chicken samples were investigated by both methods and relative accuracy, relative sensitivity and relative specificity of the real-time PCR method were determined to be 89,94 and $87 \%$, respectively. Thirty cultures blind tested were correctly identified by the real-time multiplex PCR method.

Conclusion: Real-time PCR methodology can contribute to meet the need for rapid identification and detection methods in food testing laboratories.

\section{Background}

Contaminated poultry products are widely accepted as a major source of Salmonella infections [1]. The annual cost of medical treatment for salmonellosis, in addition to loss of productivity, imposes a significant financial burden on many countries. At present more than 2,500 serotypes of Salmonella are known. Serotypes Enteritidis and Typhimurium accounted for the majority of cases of human salmonellosis in Ireland in 2006 [2]. A report on Zoonoses in Ireland in 2004 shows that of the 7,616 raw poultry meats 
sampled at processing level, 245 (3.2\%) were positive for Salmonella with the most common serotypes isolated being Enteritidis, Kentucky, Bredeney and Mbandaka [3]. The results of the European baseline survey on the prevalence of Salmonella in broiler flocks in 2005-2006 indicated $27.9 \%$ positive flocks in Ireland, compared to $23.7 \%$ in the EU overall [4]. While the prevalence of Salmonella in egg-laying flocks was $1.4 \%$ in Ireland according to the European baseline study, compared to $30.7 \%$ in the EU overall [5].

Currently, international guidelines and regulations for the detection of Salmonella sp. in foods are based on traditional cultural methods, which takes at least 5 days for confirmation of results [6]. More recently attention has focused on molecular based methods due to their sensitivity, specificity and reduced assay time. Conventional PCR based assays for Salmonella detection in foods have been widely reported [7-10]. Additionally real-time PCR assays for the specific detection of Salmonella are increasingly documented [11-19]. Both of these methods for detection of Salmonella in foods have been brought to inter-laboratory trial, the results of which support their use as international standard methods [20,21]. Real-time multiplex PCR assays for simultaneous detection of two or more genera in foods e.g. Salmonella and Campylobacter in chicken rinse fluid [22] and Salmonella and Listeria in raw sausage meat $[23,24]$ have been described. The invA gene target is most commonly used for the detection of Salmonella in PCR assays, however gene targets such as ttrRS$B C A, \operatorname{sip} B C$ and stn have been used as well [10-15,17-23]. A duplex real-time PCR assay for the detection of Salmonella Enteritidis in poultry meat and consumption eggs has been developed with primers and TaqMan probes based on the Salmonella specific invA gene and the prot6e gene located on the $S$. Enteritidis specific $60 \mathrm{~kb}$ virulence plasmid [24]. To date, conventional multiplex PCRs for serotyping in clinical isolates have been described using the $r f b$ locus and flagellar alleles as gene targets, however they have not been tested on food samples [25-27].

Rapid pathogen testing is vital to the food industry and facilitates increased public health protection. Real-time PCR methodology reduces the reporting time of results compared to the traditional microbiology method. These methods can prove advantageous to food manufacturing companies by preventing costly and damaging product recalls, as most food products are not held in warehouses pending test results.

In this paper we report the development of a real-time multiplex PCR assay for the detection of multiple Salmonella serotypes in chicken samples and assess its equivalence with the traditional cultural method, ISO 6579 (2002). The multiplex real-time PCR assay comprises four targets, aceK, which is Salmonella sp. specific and three other targets that are Salmonella serotype specific; sefA specific for serotypes Enteritidis, Dublin and Gallinarum:sdf target specific for Salmonella Enteritidis only and fliC target specific for serotypes Typhimurium and Kentucky.

\section{Methods \\ Bacterial strains used in this study}

Sixty Salmonella strains and thirty non-Salmonella strains used in the selectivity testing in this study are listed in Tables 1 and 2, respectively. Salmonella Enteritidis ATCC 13076, Salmonella Typhimurium ATCC 14028, Salmonella Kentucky NCTC 05799 and Salmonella Bredeney NCTC 05731 were used to artificially contaminate chicken samples. These serotypes were chosen for artificial inoculation experiments because they have been associated with poultry-related outbreaks of gastroenteritis in Ireland [28,29].

\section{Traditional cultural method and real-time multiplex PCR assay}

All Salmonella, non-Salmonella strains and chicken samples used in this study were tested for Salmonella by the ISO 6579:2002 European International Standard Method [6] (Figure 1). Biochemical testing was performed using api20E test strips (bioMerieux, Marcy l'Etoile, France). Serotyping was performed according to the KauffmannWhyte typing scheme using slide agglutination with standard antisera (Murex, Dublin, Ireland). The real-time multiplex PCR method comprised an $18 \mathrm{~h}$ pre-enrichment in buffered peptone water (BPW CM1049, Oxoid, Basingstoke, UK) at $37^{\circ} \mathrm{C}$, followed by $6 \mathrm{~h}$ incubation in Rappaport-Vassiliadis Soya (RVS) Peptone Broth (CM0866, Oxoid) at $41.5^{\circ} \mathrm{C}$, with subsequent DNA extraction (Figure 1).

\section{Sample DNA Extraction for real-time multiplex PCR assay} DNA was extracted from pure cultures of bacteria and chicken samples that had been enriched at $37^{\circ} \mathrm{C}$ for $18 \mathrm{~h}$ in BPW and at $41.5^{\circ} \mathrm{C}$ for $6 \mathrm{~h}$ in RVS. One $\mathrm{ml}$ of the RVS broth was collected in an eppendorf tube, centrifuged at $15,339 \times g$ for $5 \mathrm{~min}$ and the supernatant discarded. The cell pellets were resuspended in $1 \mathrm{ml}$ phosphate buffered saline (PBS, Oxoid), centrifuged at 15,339 $\times g$ for $5 \mathrm{~min}$ and the supernatant discarded. DNA extractions were performed on the cell pellet using the DNeasy Blood and Tissue kit (Qiagen, Hilden, Germany) according to manufacturer's instructions. DNA preparations were stored at $-20^{\circ} \mathrm{C}$ until use.

Primers and probes used in real-time multiplex PCR assay The design of the primers was based on the multiple alignment of Salmonella and non-Salmonella sequences of the individual genes using MegAlign Lasergene software (DNAstar, Madison WI, USA). Sequences were taken from GenBank accession numbers in the literature and nucle- 
Table I: Salmonella strains used in the selectivity testing of real-time multiplex PCR assay and traditional cultural method. $C_{\mathrm{T}}$ values are given in parentheses.

\begin{tabular}{|c|c|c|c|c|c|}
\hline \multirow[t]{2}{*}{ Salmonella serotypes } & \multirow[t]{2}{*}{ ISO 6579} & \multicolumn{4}{|c|}{ Real-time multiplex PCR } \\
\hline & & aceK & flic & $\operatorname{sef} A$ & $s d f$ \\
\hline Agona & $+\mathrm{a}$ & $+(23.31)$ & $-b$ & - & - \\
\hline Anatum & + & $+(21.67)$ & - & - & - \\
\hline Braenderup & + & $+(21.24)$ & - & - & - \\
\hline Bredeney & + & $+(21.7 \mathrm{I})$ & - & - & - \\
\hline Derby & + & $+(22.79)$ & - & - & - \\
\hline Dublin $(n=7)^{c}$ & + & $+(17.63)$ & - & $+(19.35)$ & - \\
\hline Enteritidis $(\mathrm{n}=\mathrm{I} \mathrm{I})$ & + & $+(21.35)$ & - & $+(23.36)$ & $+(23.67)$ \\
\hline Gallinarum $(n=3)$ & + & $+(26.87)$ & - & $+(27.83)$ & - \\
\hline Goldcoast & + & $+(24.35)$ & - & - & - \\
\hline Hadar & + & $+(19.68)$ & - & - & - \\
\hline Heidelberg & + & $+(21.12)$ & - & - & - \\
\hline Infantis & + & $+(23.34)$ & - & - & - \\
\hline Kentucky $(n=8)$ & + & $+(18.59)$ & $+(21.65)$ & - & - \\
\hline Livingstone & + & $+(21.90)$ & - & - & - \\
\hline London & + & $+(19.92)$ & - & - & - \\
\hline Manhattan & + & $+(17.53)$ & - & - & - \\
\hline Newport & + & $+(18.04)$ & - & - & - \\
\hline Nottingham & + & $+(21.89)$ & - & - & - \\
\hline Panama & + & $+(19.54)$ & - & - & - \\
\hline Saintpaul & + & $+(21.06)$ & - & - & - \\
\hline Senftenberg & + & $+(21.01)$ & - & - & - \\
\hline Stanley & + & $+(19.23)$ & - & - & - \\
\hline Typhimurium $(n=10)$ & + & $+(19.77)$ & $+(22.45)$ & - & - \\
\hline Uganda & + & $+(20.21)$ & - & - & - \\
\hline Virchow & + & $+(22.52)$ & - & - & - \\
\hline Gaminara & + & $+(21.03)$ & - & - & - \\
\hline
\end{tabular}

$\mathrm{a}+=$ Salmonella positive by the method.

$b_{-}=-$Salmonella negative by the method.

$\mathrm{c}=$ Mean $\mathrm{C}_{\mathrm{T}}$ values are given when $\mathrm{n}>\mathrm{I}$.

otide entries on NCBI website http:// www.ncbi.nlm.nih.gov. The gene targets used for primer design and for the real-time multiplex PCR assay and the Salmonella serotypes they detect are included in Figure 2. Four primer pairs were designed using Primer Select DNAStar Lasergene software. The specificity of the primer sequences was tested by homology searches in the nucleotide database (NCBI, nucleotide BLAST (blastn)). TIB Molbiol (Berlin, Germany) designed the TaqMan probes and the probes were labeled with reporter dyes FAM $(a c e K)$, YAK (fliC), ROX (sefA) and Cy5 (sdf). Primers and probes were purchased from TIB Molbiol and their sequences are presented in Table 3.

\section{Real-Time Multiplex PCR assay}

Real-time multiplex PCR reactions were performed with the Rotor Gene 3000 (Corbett Research, Australia) using a total volume of $25 \mu \mathrm{l}$, which was contained within a 0.2 $\mathrm{ml}$ thin-walled PCR tube. The optimal amplification reaction mixture contained $12.5 \mu \mathrm{l} 2 \times$ QuantiTect Multiplex PCR No ROX mastermix (Qiagen) containing HotStar Taq polymerase, QuantiTect multiplex PCR buffer, dNTP mix including dUTP and $11 \mathrm{mM} \mathrm{MgCl}_{2}$, a final concentration of $0.4 \mu \mathrm{M}$ for each primer and probe, $4.5 \mu \mathrm{l}$ sterile RNasefree water and $2 \mu \mathrm{l}$ of test or control DNA. Each real-time PCR assay systematically included six control reactions performed in parallel with the test samples. These positive and negative controls used as template, genomic DNA of five Salmonella strains or water respectively. Incubation conditions consisted of an initial denaturation at $95^{\circ} \mathrm{C}$ for $15 \mathrm{~min}$; followed by 35 cycles of $94^{\circ} \mathrm{C}$ for $60 \mathrm{sec}$ and $60^{\circ} \mathrm{C}$ for $90 \mathrm{sec}$. Fluorescence signals were detected in FAM, YAK, ROX and Cy5 channels. The Rotor Gene 3000 analyzer is capable of detecting four dyes simultaneously in a multiplex assay. The line for calculating the threshold cycle number $\left(\mathrm{C}_{\mathrm{T}}\right)$ for each channel was assigned to a fixed value intersecting the amplification curves in the linear region of the logarithmic plot. Any sample showing a fluorescence signal above this line was regarded as positive. Each PCR reaction gave a positive or negative result at this threshold line. Samples with $\mathrm{C}_{\mathrm{T}}$ values of less than 35 cycles were considered as positive from preliminary optimization experiments. 
Table 2: Non-Salmonella strains used in the selectivity testing of the real-time multiplex PCR assay and traditional cultural method.

\begin{tabular}{|c|c|}
\hline Non-Salmonella Strains & Type Strain Number \\
\hline E. coli & ATCC 25922 \\
\hline E. coli & NCTC 0900I \\
\hline E. coli & NDC 544 \\
\hline C. freundi & NCTC 09750 \\
\hline C. freundi & NCTC 8090 \\
\hline C. diversus & CCFRA 7119 \\
\hline C. koseri & NCTC 10768 \\
\hline E. cloacae & NCTC II933 \\
\hline E. cloacae & NCTC 10005 \\
\hline E. agglomerans & NCTC 0938I \\
\hline E. intermedius & NDC 427 \\
\hline E. aerogenes & NCTC 10006 \\
\hline E. sakazakii & NCTC II467 \\
\hline E. faecium & ATCC 35667 \\
\hline E. faecalis & NCTC 12697 \\
\hline B. cereus & NCTC 07464 \\
\hline K. oxytoca & ATCC 43086 \\
\hline K. pneumoniae & ATCC 13883 \\
\hline P. aeruginosa & NCTC 12903 \\
\hline P. putida & ATCC 49128 \\
\hline L. planatarum & ATCC 8014 \\
\hline S. haemolyticus & ATCC 29970 \\
\hline S. epidermis & Unknown \\
\hline S. saprophyticus & ATCC 15305 \\
\hline S. lactis & NCDO 2003 \\
\hline A. hydrophilia & ATCC 35654 \\
\hline A. globiformis & ATCC 8010 \\
\hline L. mesenteroides & ATCC 8293 \\
\hline A. calcoaceticus & ATCC 23055 \\
\hline P. mirabilis & DSM 4479 \\
\hline
\end{tabular}

\section{Selectivity testing}

Sixty Salmonella strains (10 CFU/ml) and thirty non-Salmonella $(1,000 \mathrm{CFU} / \mathrm{ml})$ strains were tested by both the traditional cultural method and real-time multiplex PCR assay. The strains were cultured in $10 \mathrm{ml} \mathrm{BPW}$ at $37^{\circ} \mathrm{C}$ for $18 \mathrm{~h}$ prior to decimal dilution in Maximum Recovery Diluent (MRD CM0733, Oxoid) to obtain the required inoculation level. One $\mathrm{ml}$ of this dilution was then transferred to $9 \mathrm{ml} \mathrm{BPW}$ at $37^{\circ} \mathrm{C}$ for $18 \mathrm{~h}$ and a $0.1 \mathrm{ml}$ aliquot of this was added to $10 \mathrm{ml}$ RVS broth at $41.5^{\circ} \mathrm{C}$ for $6 \mathrm{~h}$. One $\mathrm{ml}$ of the RVS broth was then collected in an eppendorf tube for DNA extraction as previously described and subsequent real-time multiplex PCR. A $2 \mu \mathrm{l}$ aliquot of the DNA extract was used as template in the real-time multiplex PCR assay.

Artificial contamination of chicken skin and chicken meat Pre-packed whole chickens were purchased from local supermarkets and were tested for the presence of Salmonella sp. by enrichment of $25 \mathrm{~g}$ chicken skin and chicken meat in $225 \mathrm{ml} \mathrm{BPW} \mathrm{(Oxoid)} \mathrm{at} 37^{\circ} \mathrm{C}$ for $18 \mathrm{~h}$, and subsequent plating on Xylose Lysine Desoxycholate agar
(XLD CM0469, Oxoid) at $37^{\circ} \mathrm{C}$ for $18 \mathrm{~h}$. As no Salmonella sp. was detected, the chicken was used for subsequent artificial contamination experiments.

Chicken skin and chicken meat samples (25 g portions) were artificially contaminated individually with four Salmonella serotypes (Enteritidis ATCC 13076, Typhimurium ATCC 14028, Kentucky NCTC 05799 and Bredeney NCTC 05731) at four levels of contamination $(0,1-10,10-100$, $100-1,000 \mathrm{CFU} / 25 \mathrm{~g})$. The four strains were cultured in $10 \mathrm{ml} \mathrm{BPW}$ at $37^{\circ} \mathrm{C}$ for $18 \mathrm{~h}$ prior to decimal dilution in MRD (Oxoid) to obtain the four different levels of contamination. Twenty-five gram portions of chicken samples were inoculated with $1 \mathrm{ml}$ of each level of inoculation, placed in stomacher bags and $225 \mathrm{ml}$ of BPW was added. The mixture was homogenized in a stomacher (Seward, London, United Kingdom) for $1 \mathrm{~min}$ and immediately incubated at $37^{\circ} \mathrm{C}$ for $18 \mathrm{~h}$. The precise numbers of CFU introduced into the chicken skin and chicken meat was determined by plating each level of inoculation on Tryptone Soya Agar plates (TSA CM0131, Oxoid), followed by incubation at $37^{\circ} \mathrm{C}$ for $24 \mathrm{~h}$. After pre-enrichment in BPW, the cultures were subdivided into two aliquots of RVS broth: one for analysis by the traditional culture method and the second for the real-time multiplex PCR assay. A total of thirty-two chicken skin and chicken meat samples, were analyzed in triplicate by both the ISO 6579 and real-time multiplex PCR methods.

\section{Naturally contaminated chicken skin samples}

A total of sixty-three $25 \mathrm{~g}$ chicken skin samples from naturally contaminated whole chickens, crowns, legs and breasts were obtained from local butchers in the Dublin area. All samples were tested for Salmonella by both the ISO 6579 method and real-time multiplex PCR assay.

\section{Blind testing of cultures}

Thirty cultures on solid media were received for blind testing from a collaborating group to assess the real-time multiplex PCR assay. One $\mathrm{ml}$ of an overnight BPW culture of the blind samples was transferred to $9 \mathrm{ml} \mathrm{BPW}$ at $37^{\circ} \mathrm{C}$ for $18 \mathrm{~h}$ and a $0.1 \mathrm{ml}$ aliquot was added to $10 \mathrm{ml}$ RVS broth at $41.5^{\circ} \mathrm{C}$ for $6 \mathrm{~h}$. One $\mathrm{ml}$ of the RVS broth was then collected in an eppendorf tube for DNA extraction as described previously and subsequent real-time mutiplex PCR.

\section{Statistical analysis and terms used}

Relative sensitivity, specificity and accuracy were calculated according to the MICROVAL protocol [30]. The formulas used for the analysis were:

(1) Relative accuracy: $\mathrm{AC}=\frac{(\mathrm{PA}+\mathrm{NA})}{\mathrm{N}} \times 100 \%$ 


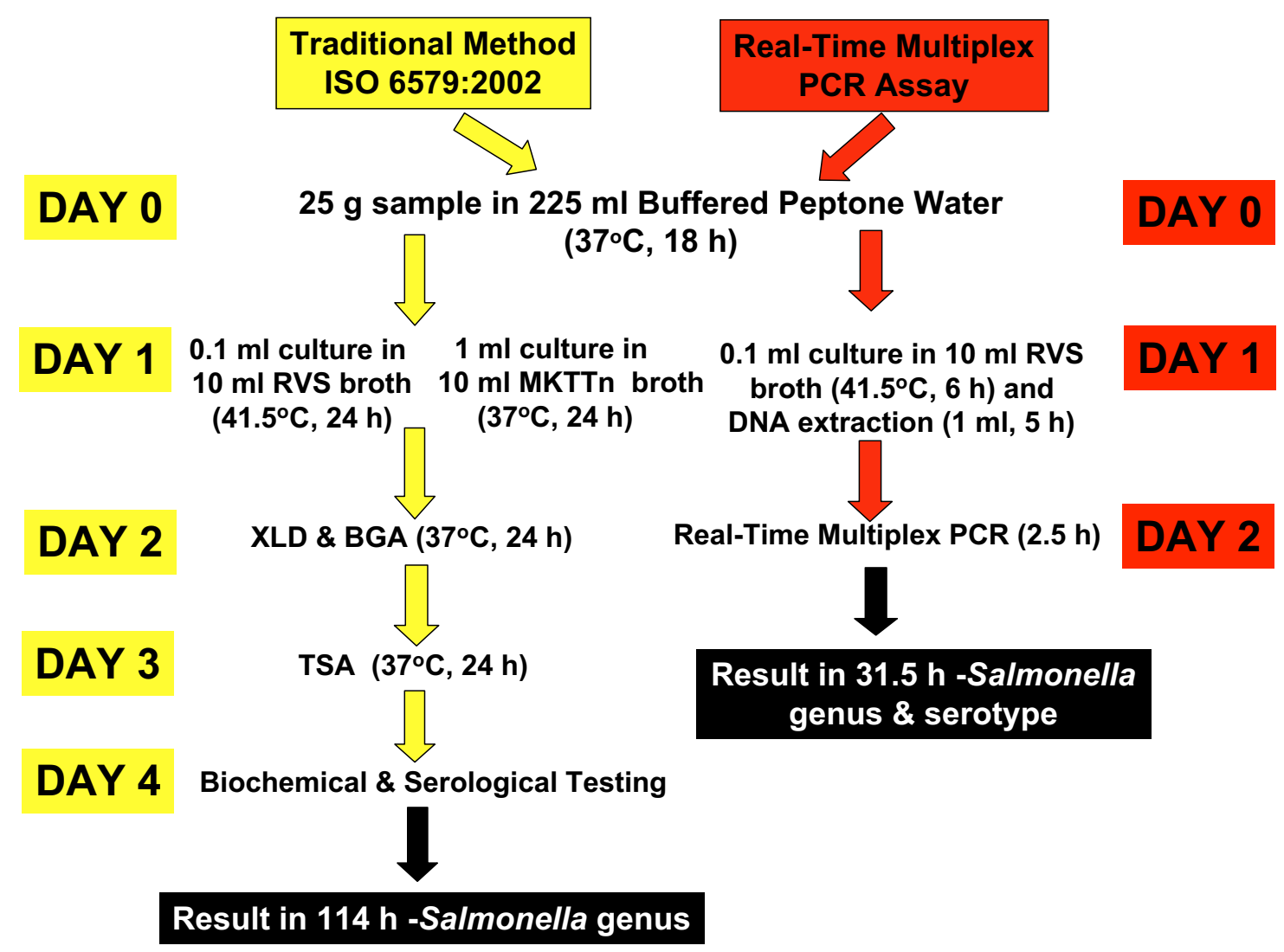

Figure I

Flow diagram of methodology in the traditional cultural method and the real-time multiplex PCR assay.

(2) Relative specificity: $\mathrm{SP}=\frac{\mathrm{NA}}{\mathrm{N}-} \times 100 \%$

(3) Relative sensitivity: $\mathrm{SE}=\frac{\mathrm{PA}}{\mathrm{N}+} \times 100 \%$

[ Where;

PA is the positive agreement between culture and PCR methods;

NA is the negative agreement between culture and PCR methods;

PD are the false positives by PCR method;

ND are the false negatives by PCR method;

$\mathrm{N}$ is the total number of samples $(\mathrm{NA}+\mathrm{PA}+\mathrm{PD}+\mathrm{ND})$;
$\mathrm{N}$ - is the total number of negative results with the reference method (NA+PD) and

$\mathrm{N}+$ is the total number of positive results with the reference method $(\mathrm{PA}+\mathrm{ND})]$.

Relative sensitivity is the ability of the alternative method (real-time multiplex PCR) to detect the analyte when it is detected by the reference method (traditional culture method ISO 6579) in the presence of a biological matrix. Relative specificity is the ability of the real-time multiplex PCR to not detect the target organism when it is not detected by the reference method. The relative accuracy is the degree of correspondence between the response obtained by the alternative method and the reference method on identical samples [30]. 


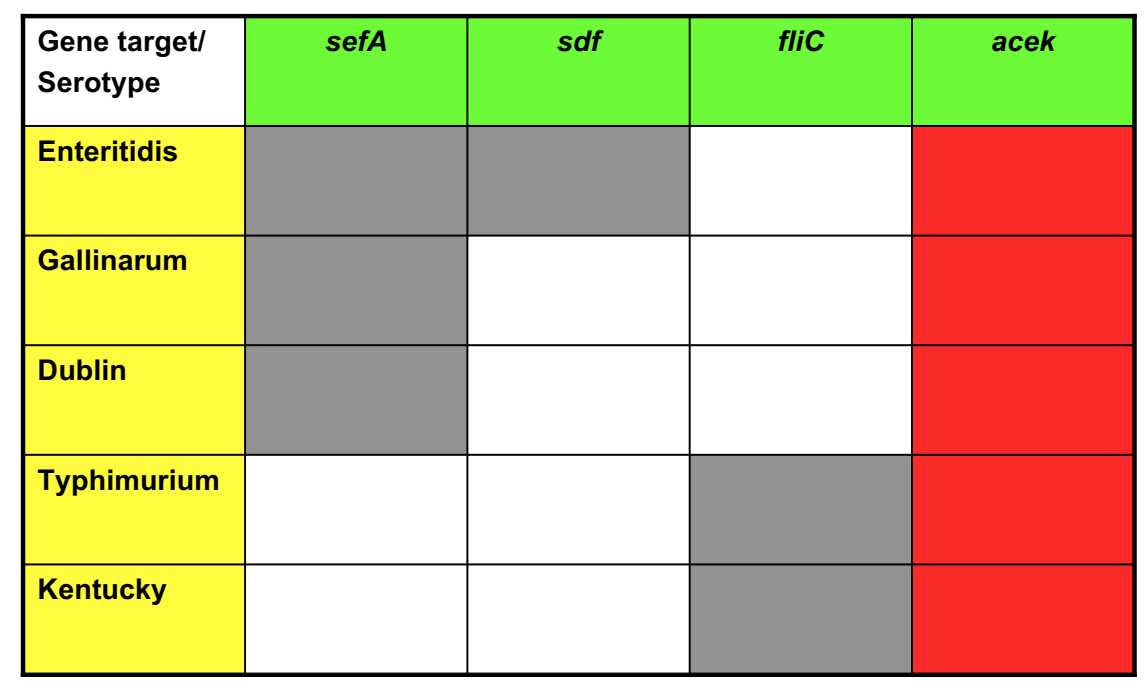

Figure 2

Gene targets used in real-time multiplex PCR assay and the Salmonella serotypes they detect.

\section{Results \\ Selectivity study}

The sixty Salmonella strains were confirmed as Salmonella positive by the traditional cultural method. These strains, comprising 26 different Salmonella serotypes, all demonstrated positive results for the aceK target in the real-time multiplex PCR assay (Table 1). Testing of the fliC serotype specific target yielded positive results for serotypes Typhimurium and Kentucky only and negative results for all other Salmonella serotypes tested. The sefA serotype specific target was positive for serotypes Enteritidis, Dublin, and Gallinarum and gave negative results for all other Salmonella serotypes. The $s d f$ serotype specific target was specific for all Salmonella Enteritidis strains only and was not amplified in the other Salmonella serotypes tested. The thirty pure culture non-Salmonella strains listed in Table 2 yielded negative results by the traditional cultural method. The non-Salmonella strains also yielded negative results by the four gene targets aceK, sefA, sdf and fliC in the real-time multiplex PCR assay. The selectivity study verified that only Salmonella strains were detected by both methods and that the gene targets $s d f$, sefA and fliC also correctly identified the serotype where appropriate. The selectivity study also confirmed that no cross reactivity ocurred with the non-Salmonella strains tested.

\section{Detection of Salmonella in artificially contaminated samples}

All artificially contaminated chicken samples tested positive for Salmonella by both the traditional cultural method and real-time multiplex PCR and all un-inoculated control samples tested negative by both methods (Table 4). The Salmonella-positive chicken samples were identified correctly at the serotype level by the real-time multiplex
PCR assay. Mean $\mathrm{C}_{\mathrm{T}}$ values obtained by the detection channels ranged from 19 to 28 cycles. The $\mathrm{C}_{\mathrm{T}}$ values given cannot be used for quantitative interpretations because of the enrichment of each sample before the real-time multiplex PCR assay. The results from the artificially contaminated samples indicated that both methods are sensitive and able to detect to a level as low as 1-10 CFU of Salmonella in $25 \mathrm{~g}$ of chicken skin and chicken meat. The results from the multiplex real-time PCR assay were in complete agreement with the ISO 6579 method in three independent artificial inoculation experiments.

\section{Detection of Salmonella in naturally contaminated samples}

Fifteen of the sixty-three naturally contaminated chicken skin samples were Salmonella positive by both methods (PA) and all fifteen samples were identified as either serotypes Typhimurium or Kentucky by the real-time multiplex PCR (Table 5). Fourty-one of the sixty three samples yielded negative results for Salmonella by both methods (NA). One sample was Salmonella-positive by the traditional cultural method and Salmonella negative by the real-time multiplex PCR (ND). Six samples were positive for Salmonella by real-time multiplex PCR and negative by the traditional cultural method (PD). Of these six samples positive for Salmonella only by real-time multiplex PCR, four were identified to the serotype level as Typhimurium or Kentucky as positive signals were detected in the YAK channel as well as the FAM channel. Mean $\mathrm{C}_{\mathrm{T}}$ values obtained by the detection channels ranged from 19 to 32 cycles. The $\mathrm{C}_{\mathrm{T}}$ values given cannot be used for quantitative interpretations because of the enrichment of each sample before real-time PCR. Relative accuracy, relative sensitivity 
Table 3: Oligonucleotide primers and probes used in real-time multiplex PCR assay.

\begin{tabular}{|c|c|c|c|c|c|}
\hline Target gene & Primer or Probe & Sequence $\left(5^{\prime}-3^{\prime}\right)$ & $\operatorname{Tm}\left({ }^{\circ} \mathrm{C}\right)$ & Amplicon Size (bp) & $\begin{array}{l}\text { Reference or } \\
\text { Accession No. }\end{array}$ \\
\hline \multirow[t]{3}{*}{$\operatorname{sef} A$} & Forward & GTGGTTCAGGCAGCAGTTACT & 61.1 & 334 & LII008 \\
\hline & Reverse & CAGGGACATTTAGCGTTTCTTGAG & 59.7 & & \\
\hline & Probe & ROX-CAGCTCAGAATACAACATCAGCCAACTGG-BBQ & 66.2 & & \\
\hline \multirow[t]{3}{*}{ flic } & Forward & CCCCGCTTACAGGTGGACTAC & 60.2 & 433 & AY64972I \\
\hline & Reverse & AGCGGGTTTTCGGTGGTTGT & 63.6 & & \\
\hline & Probe & YAK-TAAAGCCGCATTGACAGCAGCAGGTG-BBQ & 69.8 & & \\
\hline \multirow[t]{3}{*}{ aceK } & Forward & CCGCGCTGGTTGAGTGG & 62.0 & 240 & U43344 \\
\hline & Reverse & GCGGGGCGAATTTGTCTTTA & 60.3 & & \\
\hline & Probe & FAM-AACCACTGCCGAACTGTATATGGCGA-BBQ & 65.0 & & \\
\hline \multirow[t]{3}{*}{$s d f$} & Forward & AAATGTGTTTTATCTGATGCAAGAGG & 57.6 & 299 & {$[35]$} \\
\hline & Reverse & GTTCGTTCTTCTGGTACTTACGATGAC & 58.7 & & \\
\hline & Probe & Сy5-CGAATGGTGAGCAGACAACAGGCTGATTTA-BBQ & 68.4 & & This study \\
\hline
\end{tabular}

and relative specificity of the real-time PCR method were determined to be 89,94 and $87 \%$, respectively.

\section{Detection of Salmonella in blind samples}

As part of the blind testing, there was a discrepancy in results with one of the blind samples (BS11) which was identified correctly by the real-time multiplex PCR (Table 6). BS11 was identified as Salmonella-positive in the FAM channel of the real-time multiplex PCR assay and confirmed by biochemical and serology testing. However the colloborating group reported that it was a non-Salmonella isolate.

\section{Discussion}

The aim of this study was to develop a rapid detection method for multiple Salmonella serotypes based on realtime multiplex PCR and to compare it to the traditional cultural method. The detection method contained a twostep enrichment procedure comprising a non-selective and a selective enrichment step to detect Salmonella in chicken samples. The overnight pre-enrichment step was required to increase the number of viable cells and to effectively dilute inhibitory substances present in the sample. The use of the second selective enrichment for 6 hours also dilutes PCR inhibitors possibly derived from the food matrix and suppresses the growth of background flora. This was followed by DNA extraction and real-time multiplex PCR. Potential inhibitory substances in foods, including fats, glycogen, organic and phenolic compounds, can affect the PCR reaction [31-33]. However several techniques can be employed to overcome this problem such as simple dilution of the sample. Methods that use secondary enrichment steps will, in general, be less prone to inhibitory effects from the sample matrix than those performed from a primary culture [32].

For the development of the real-time multiplex PCR assay, primers were designed for four targets, one specific for Sal- monella species and the other three targets were serotype specific; detecting serotypes commonly reported in Ireland. The aceK gene was chosen as a target for the detection of Salmonella sp. in the real-time multiplex PCR assay and its specificity was confirmed with at least thirty nonSalmonella strains in this study. The aceK gene encodes a bi-functional regulatory enzyme (isocitrate dehydrogenase kinase/phosphatase, IDH K/P) that catalyzes phosphorylation and dephosphorylation of isocitrate dehydrogenase and thereby controls the flux of isocitrate through the tricarboxylic acid cycle and the glyoxylate bypass [34]. The fliC target is specific for serotypes Typhimurium and Kentucky, which both encode the i-antigen specific phase 1 flagellin and both are poultry-associated serotypes. Further, the i-antigen is also expressed in uncommon serotypes such as Aberdeen, Bergen and Kedougou. The gene target $s d f$ was chosen from the literature, it was identified by subtractive hybridization and is specific for serotype Enteritidis [35]. sdf is chromosomally encoded, yet its function is unknown [35]. Salmonella Enteritidis is most common serotype reported in poultryassociated gastroenteritis outbreaks worldwide [36]. sefA encodes the SEF14 fimbrial antigen and the distribution of SEF14 fimbriae is limited to a subset of group D Salmonella [37]. The sefA target detects serotype Enteritidis, hence it corroborates the results from the sdf target. sefA also detects the poultry-associated serotype Gallinarum. It detects serotype Dublin also, although this serotype is more commonly associated with cattle, it has been found on occasion in poultry samples. The sefA target may also identify infrequent Salmonella serogroup D serotypes such as Rostock, Berta, Pullorum and Seremban. This is the first report wherein these four gene targets were incorporated into a unified real-time multiplex PCR assay for the detection of multiple Salmonella serotypes in chicken samples.

Selectivity testing of both methods yielded $100 \%$ inclusivity and $100 \%$ exclusivity. The Salmonella strains used for 
Table 4: Results of the real-time multiplex PCR assay compared to the traditional cultural method for the detection of Salmonella from artificially contaminated chicken skin and chicken meat samples

\begin{tabular}{|c|c|c|c|c|c|c|c|}
\hline \multirow[t]{2}{*}{ Food Type } & \multirow[t]{2}{*}{ Salmonella serotype } & \multirow[t]{2}{*}{ Estimated CFU by plating } & \multirow[t]{2}{*}{ ISO 6579} & \multicolumn{4}{|c|}{ Real-time multiplex PCR } \\
\hline & & & & aceK & flic & $\operatorname{sefA}$ & $s d f$ \\
\hline \multirow[t]{4}{*}{ Chicken skin } & Enteritidis & 0 & $-\mathrm{a}$ & - & - & - & - \\
\hline & & 3 & $+b$ & $+(28.14)$ & - & $+(27.70)$ & $+(26.99)$ \\
\hline & & 32 & + & $+(24.94)$ & - & $+(25.15)$ & $+(24.5 \mathrm{I})$ \\
\hline & & 168 & + & $+(22.52)$ & - & $+(22.32)$ & $+(21.68)$ \\
\hline \multirow{4}{*}{ Chicken meat } & Enteritidis & 0 & - & - & - & - & - \\
\hline & & 5 & + & $+(20.58)$ & - & $+(20.09)$ & $+(19.88)$ \\
\hline & & 36 & + & $+(20.20)$ & - & $+(19.96)$ & $+(19.57)$ \\
\hline & & 222 & + & $+(19.67)$ & - & $+(19.67)$ & $+(19.05)$ \\
\hline \multirow[t]{4}{*}{ Chicken skin } & Typhimurium & 0 & - & - & - & - & - \\
\hline & & 3 & + & $+(24.12)$ & $+(23.46)$ & - & - \\
\hline & & 34 & + & $+(22.18)$ & $+(21.00)$ & - & - \\
\hline & & 257 & + & $+(21.95)$ & $+(19.57)$ & - & - \\
\hline \multirow[t]{4}{*}{ Chicken meat } & Typhimurium & 0 & - & - & - & - & - \\
\hline & & 7 & + & $+(23.19)$ & $+(22.75)$ & - & - \\
\hline & & 54 & + & $+(21.39)$ & $+(21.19)$ & - & - \\
\hline & & 305 & + & $+(20.84)$ & $+(20.42)$ & - & - \\
\hline \multirow[t]{4}{*}{ Chicken skin } & Kentucky & 0 & - & - & - & - & - \\
\hline & & 6 & + & $+(26.28)$ & $+(25.94)$ & - & - \\
\hline & & 48 & + & $+(24.25)$ & $+(23.70)$ & - & - \\
\hline & & 280 & + & $+(22.12)$ & $+(2 \mathrm{I} .4 \mathrm{I})$ & - & - \\
\hline \multirow[t]{4}{*}{ Chicken meat } & Kentucky & 0 & - & - & - & - & - \\
\hline & & 5 & + & $+(23.55)$ & $+(22.33)$ & - & - \\
\hline & & 52 & + & $+(21.15)$ & $+(19.93)$ & - & - \\
\hline & & 277 & + & $+(20.57)$ & $+(19.49)$ & - & - \\
\hline \multirow[t]{4}{*}{ Chicken skin } & Bredeney & 0 & - & - & - & - & - \\
\hline & & 6 & + & $+(22.46)$ & - & - & - \\
\hline & & 60 & + & $+(21.58)$ & - & - & - \\
\hline & & 397 & + & $+(22.00)$ & - & - & - \\
\hline \multirow[t]{4}{*}{ Chicken meat } & Bredeney & 0 & - & - & - & - & - \\
\hline & & 9 & + & $+(22.37)$ & - & - & - \\
\hline & & 75 & + & $+(21.69)$ & - & - & - \\
\hline & & 338 & + & $+(22.23)$ & - & - & - \\
\hline
\end{tabular}

$\mathrm{C}_{\mathrm{T}}$ values, in parentheses, are means of triplicates at a fixed threshold. $a_{-}=$Salmonella negative by the method.

$\mathrm{b}+=$ Salmonella positive by the method

the selectivity testing represented Salmonella serotypes that have been frequently reported in Ireland over the past ten years according to the annual reports on salmonellosis by the Health Protection Surveillance Centre. The nonSalmonella strains chosen for the selectivity testing were

Table 5: Results of the traditional cultural method and real-time multiplex PCR assay for Salmonella detection from naturally contaminated chicken skin samples.

\begin{tabular}{lccc}
\hline & \multicolumn{3}{c}{ ISO 6579 } \\
& + +a & $-\mathrm{b}$ \\
\hline Real-time Multiplex & + & 15 & $6 \mathrm{c}$ \\
PCR & - & 1 & 41 \\
\hline
\end{tabular}

$\mathrm{a}+=$ Salmonella positive by the method.

$b_{-}=$Salmonella negative by the method.

c $=$ Four of these samples were identified at the serotype level as

Typhimurium or Kentucky. representative of food-borne pathogens and found in the same environments as Salmonella. Blind testing of cultures by the real-time multiplex PCR method indicated that the gene targets in the real-time multiplex PCR method correctly identified the thirty blind culture samples. Both methods allowed sensitive detection of Salmonella in artificially contaminated chicken samples, yielding positive results even at the lowest contamination levels tested (1$10 \mathrm{CFU} / 25$ g chicken samples).

Data from fifty-six of the sixty-three naturally contaminated chicken skin samples were in agreement by both methods. One of the samples tested positive by traditional culture and negative by real-time multiplex PCR. This may have arisen as a result of dislodgement of the pellet during a washing step with PBS. Six of sixty-three naturally contaminated samples were positive by the realtime multiplex PCR assay and negative by the traditional 
Table 6: Results of the real-time multiplex PCR assay for the detection of Salmonella from blind culture samples compared to the reported identification from another laboratory.

\begin{tabular}{|c|c|c|c|c|c|c|}
\hline \multirow[t]{2}{*}{ Lab. ID } & \multicolumn{4}{|c|}{ Real-time multiplex PCR } & \multirow[t]{2}{*}{ Real-time Multiplex PCR Result } & \multirow[t]{2}{*}{ Reported Identification by other lab } \\
\hline & aceK & flic & sefA & $s d f$ & & \\
\hline BSI & $+\mathrm{ta}(23.94)$ & $-b$ & - & - & Salmonella & Gaminara \\
\hline BS2 & $+(24.01)^{c}$ & - & $+(23.0 \mathrm{I})$ & - & Gallinarum/Dublin & Dublin \\
\hline BS3 & - & - & - & - & $N D^{d}$ & Non-Salmonella \\
\hline BS4 & $+(24.16)$ & - & - & - & Salmonella & Branderup \\
\hline BS5 & $+(24.77)$ & - & - & - & Salmonella & Manhattan \\
\hline BS6 & $+(23.89)$ & - & - & - & Salmonella & Nottingham \\
\hline BS7 & - & - & - & - & ND & Non-Salmonella \\
\hline BS8 & $+(25.36)$ & - & - & - & Salmonella & Anatum \\
\hline BS9 & $+(22.93)$ & - & - & - & Salmonella & SanDiego \\
\hline BSIO & $+(24.02)$ & $+(20.40)$ & - & - & Typhimurium/Kentucky & Kentucky \\
\hline BSI Ie & $+(23.10)$ & - & - & - & Salmonella & Non-Salmonella \\
\hline BSI2 & $+(23.78)$ & - & - & - & Salmonella & London \\
\hline $\mathrm{BS} / 3$ & $+(24.67)$ & - & - & - & Salmonella & Virchow \\
\hline $\mathrm{BSI} 4$ & $+(24.79)$ & - & - & - & Salmonella & Livingstone \\
\hline BSI5 & - & - & - & - & ND & Non-Salmonella \\
\hline BSI6 & $+(22.90)$ & - & - & - & Salmonella & Derby \\
\hline BSI7 & - & - & - & - & ND & Non-Salmonella \\
\hline $\mathrm{BS} \mid 8$ & $+(23.42)$ & - & $+(22.03)$ & - & Gallinarum & Gallinarum \\
\hline $\mathrm{BS} 19$ & $+(24.33)$ & - & - & - & Salmonella & Saintpaul \\
\hline BS20 & $+(25.45)$ & - & - & - & Salmonella & Agona \\
\hline BS2I & - & - & - & - & ND & Non-Salmonella \\
\hline BS22 & $+(23.04)$ & $+(20.55)$ & - & - & Typhimurium/Kentucky & Typhimurium \\
\hline $\mathrm{BS} 23$ & $+(22.59)$ & $+(20.03)$ & - & - & Typhimurium/Kentucky & Typhimurium \\
\hline BS24 & $+(23.59)$ & - & - & - & Salmonella & Hadar \\
\hline BS25 & $+(23.49)$ & - & - & - & Salmonella & Heidelberg \\
\hline BS26 & $+(23.12)$ & - & - & - & Salmonella & Newport \\
\hline BS27 & $+(23.73)$ & $+(22.68)$ & - & - & Typhimurium/Kentucky & Typhimurium \\
\hline BS28 & $+(23.96)$ & - & - & - & Salmonella & Reading \\
\hline BS29 & $+(22.56)$ & $+(21.35)$ & - & - & Typhimurium/Kentucky & Typhimurium \\
\hline BS30 & $+(22.79)$ & - & - & - & Salmonella & Infantis \\
\hline
\end{tabular}

$\mathrm{a}+=$ Salmonella positive by method.

$b_{-}=$Salmonella negative by method.

$c=C_{T}$ values in parentheses.

dND = Salmonella not detected.

e = BSI I was identified as Salmonella-positive by aceK target and confirmed by biochemical and serology testing, while the another laboratory

reported that it was a non-Salmonella isolate.

cultural method. This may be attributable to the fact that target cells may have been injured or died despite the enrichment procedures i.e. were non-culturable but detectable by PCR. Similar to our findings, Schrank et al [38] and Loftstrom et al [39] noted that PCR following enrichment detected more Salmonella in poultry samples compared to conventional culture. Furthermore, it was reported that to be able to distinguish between salmonellae and other bacteria growing on selective solid agar, the number of Salmonella cells must be at least $10^{4} \mathrm{CFU} / \mathrm{ml}$ after enrichment in tetrathionate broth (TTB) before they are detectable on selective solid media [40]. This could explain culture negativity in the samples that are PCR positive. Salmonella was detected in the presence of a large background flora in the naturally contaminated chicken skin samples, which was subsequently identified by biochemical testing as E. coli, Enterobacter cloacae, Klebsiella pneumoniae, Citrobacter freundi and Pseudomonas.
The use of an internal amplification control (IAC) is becoming mandatory for diagnostic PCR testing of foodborne pathogens as it indicates the presence of DNA polymerase inhibitors, errors caused by PCR components or malfunctions of the thermal cycler [41]. In this realtime multiplex PCR assay the simultaneous detection of Salmonella specific aceK target sequence functions as a surrogate IAC for Salmonella DNA in the sample. However in the event of chicken samples being negative for all four targets in the real-time PCR assay, the possibility remains that inhibitors are present in the extracted DNA leading to a false negative result that cannot be excluded.

\section{Conclusion}

This study reports a rapid real-time multiplex PCR assay using four primer sets and four TaqMan probes for the detection of multiple Salmonella serotypes. The assay performed equally as well as the traditional cultural method 
and facilitated the sensitive detection of Salmonella in artificially contaminated chicken skin and chicken meat samples. However, further experiments should focus on inclusion of a universal IAC into the real-time multiplex PCR assay, automation of the DNA extraction, analysis of a larger number of naturally contaminated samples including additional food types and an inter-laboratory trial. The real-time multiplex PCR assay has the potential to be used in routine diagnostic laboratories when it is necessary to identify the serotype for surveillance studies and as a rapid screening tool in food testing laboratories to quickly identify Salmonella-positive samples.

\section{Authors' contributions}

EO'R designed and carried out all the experimental work. EO'R drafted the manuscript. EMcC, CB and SMcG provided some of the bacterial strains used in this study and collaborated on the culture enrichment studies. SF, PW, GD and TB conceived this study. All authors read and approved the final manuscript.

\section{Acknowledgements}

This research has been carried out with the financial support of the Food Institutional Research Measure (FIRM) administered by the Irish Department of Agriculture, Fisheries and Food. I would like to thank Teresa Quinn and Dr. Carol lversen for critical reading of the manuscript and Joseph Meade for technical support throughout the experiments.

\section{References}

I. Cogan TA, Humphrey TJ: The rise and fall of Salmonella Enteritidis in the UK. J Appl Microbiol 2003, 94(Suppl): I I4S-I I 9S.

2. Foley B, McKeown P, de Lappe N, Cormican M: Salmonellosis in Ireland, 2006. EPI-Insight 2007, 8(1 0):2-3.

3. FSAI: Report on Zoonoses in Ireland, 2004. Dublin 2006: I-46.

4. EFSA: Report of the Task Force on Zoonoses Data Collection on the Analysis of the baseline survey on the prevalence of Salmonella in broiler flocks of Gallus gallus, in the EU, 20052006. Part A: Salmonella prevalence estimates. The EFSA Journal 2007: I-85.

5. EFSA: Preliminary Report on the Analysis of the Baseline Study on the Prevalence of Salmonella in Laying Hen Flocks of Gallus gallus. The EFSA Journal 2006: I-7I.

6. Anonymous: Microbiology of Food and Animal Feeding StuffsHorizontal Method for the Detection of Salmonella (EN ISO 6579:2002). International Organization for Standardization, Geneva, Switzerland; 2002.

7. Moreira AN, Conceicao FR, Conceicao Rde C, Ramos RJ, Carvalhal JB, Dellagostin OA, Aleixo JA: Detection of Salmonella typhimurium in raw meats using in-house prepared monoclonal antibody coated magnetic beads and PCR assay of the fimA gene. J Immunoassay Immunochem 2008, 29(I):58-69.

8. Whyte P, Mc Gill K, Collins JD, Gormley E: The prevalence and PCR detection of Salmonella contamination in raw poultry. Vet Microbiol 2002, 89(I):53-60.

9. Myint MS, Johnson YJ, Tablante NL, Heckert RA: The effect of preenrichment protocol on the sensitivity and specificity of PCR for detection of naturally contaminated Salmonella in raw poultry compared to conventional culture. Food Microbiol 2006, 23(6):599-604.

10. Makino S, Kurazono $H$, Chongsanguam M, Hayashi $H$, Cheun $H$, Suzuki S, Shirahata T: Establishment of the PCR system specific to Salmonella spp. and its application for the inspection of food and fecal samples. J Vet Med Sci I 999, 6 I (I I ): I 245-I 247.

II. Nam HM, Srinivasan V, Gillespie BE, Murinda SE, Oliver SP: Application of SYBR green real-time PCR assay for specific detec- tion of Salmonella spp. in dairy farm environmental samples. Int J Food Microbiol 2005, I 02(2): I6I-I7I.

12. Chen S, Yee A, Griffiths M, Larkin C, Yamashiro CT, Behari R, PaszkoKolva C, Rahn K, De Grandis SA: The evaluation of a fluorogenic polymerase chain reaction assay for the detection of Salmonella species in food commodities. Int J Food Microbiol 1997, 35(3):239-250.

13. Josefsen MH, Krause M, Hansen F, Hoorfar J: Optimization of a I2hour TaqMan PCR-based method for detection of Salmonella bacteria in meat. Appl Environ Microbiol 2007, 73(9):3040-3048.

14. Malorny B, Paccassoni E, Fach P, Bunge C, Martin A, Helmuth R: Diagnostic real-time PCR for detection of Salmonella in food. Appl Environ Microbiol 2004, 70( I 2):7046-7052.

15. Wolffs PF, Glencross K, Thibaudeau R, Griffiths MW: Direct quantitation and detection of salmonellae in biological samples without enrichment, using two-step filtration and real-time PCR. Appl Environ Microbiol 2006, 72(6):3896-3900.

16. De Medici D, Croci L, Delibato E, Di Pasquale S, Filetici E, Toti L: Evaluation of DNA extraction methods for use in combination with SYBR green I real-time PCR to detect Salmonella enterica serotype enteritidis in poultry. Appl Environ Microbiol 2003, 69(6):3456-346I.

17. Hein I, Flekna G, Krassnig M, Wagner M: Real-time PCR for the detection of Salmonella spp. in food: An alternative approach to a conventional PCR system suggested by the FOOD-PCR project. J Microbiol Methods 2006, 66(3):538-547.

18. Perelle S, Dilasser F, Malorny B, Grout J, Hoorfar J, Fach P: Comparison of PCR-ELISA and LightCycler real-time PCR assays for detecting Salmonella spp. in milk and meat samples. Mol Cell Probes 2004, I 8(6):409-420.

19. Ellingson JL, Anderson JL, Carlson SA, Sharma VK: Twelve hour real-time PCR technique for the sensitive and specific detection of Salmonella in raw and ready-to-eat meat products. Mol Cell Probes 2004, I 8(1):5 I-57.

20. Malorny B, Made D, Teufel P, Berghof-Jager C, Huber I, Anderson A, Helmuth R: Multicenter validation study of two blockcyclerand one capillary-based real-time PCR methods for the detection of Salmonella in milk powder. Int J Food Microbiol 2007, I I 7(2):2||-2|8.

2I. Malorny B, Hoorfar J, Hugas M, Heuvelink A, Fach P, Ellerbroek L, Bunge C, Dorn C, Helmuth R: Interlaboratory diagnostic accuracy of a Salmonella specific PCR-based method. Int J Food Microbiol 2003, 89(2-3):24I-249.

22. Wolffs PF, Glencross K, Norling B, Griffiths MW: Simultaneous quantification of pathogenic Campylobacter and Salmonella in chicken rinse fluid by a flotation and real-time multiplex PCR procedure. Int J Food Microbiol 2007, I I 7(I):50-54.

23. Wang $X$, Jothikumar N, Griffiths MW: Enrichment and DNA extraction protocols for the simultaneous detection of Salmonella and Listeria monocytogenes in raw sausage meat with multiplex real-time PCR. J Food Prot 2004, 67(I): I 89-192.

24. Malorny B, Bunge C, Helmuth R: A real-time PCR for the detection of Salmonella Enteritidis in poultry meat and consumption eggs. J Microbiol Methods 2007, 70(2):245-25I.

25. Herrera-Leon S, McQuiston JR, Usera MA, Fields PI, Garaizar J, Echeita MA: Multiplex PCR for distinguishing the most common phase-I flagellar antigens of Salmonella spp. J Clin Microbiol 2004, 42(6):258I-2586.

26. Herrera-Leon S, Ramiro R, Arroyo M, Diez R, Usera MA, Echeita MA Blind comparison of traditional serotyping with three multiplex PCRs for the identification of Salmonella serotypes. Res Microbiol 2007, I 58(2): I22-127.

27. Kim S, Frye JG, Hu J, Fedorka-Cray PJ, Gautom R, Boyle DS: Multiplex PCR-based method for identification of common clinical serotypes of Salmonella enterica subsp. enterica. J Clin Microbiol 2006, 44(1 0):3608-36I5.

28. Moore JE, Murray L, Fanning S, Cormican M, Daly M, Delappe N, Morgan B, Murphy PG: Comparison of phenotypic and genotypic characteristics of Salmonella bredeney associated with a poultry-related outbreak of gastroenteritis in Northern Ireland. J Infect 2003, 47( I):33-39.

29. Crilly J, Power E, Fanning S, Cryan B, Buckley J: Epidemiology of Salmonella infection in the South of Ireland. Irish Journal of Agriculture and Food Research 2001:215-226. 
30. Anonymous: Microbiology of Food and Animal Feeding StuffsProtocol for the Validation of Alternative Methods (ISO 16 1 40:2003). European Committee for Standardization; 2003.

31. Rossen L, Norskov P, Holmstrom K, Rasmussen OF: Inhibition of PCR by components of food samples, microbial diagnostic assays and DNA-extraction solutions. Int J Food Microbiol I992, I 7(I):37-45.

32. Mozola MA: Genetics-based methods for detection of Salmonella spp. in foods. J AOAC Int 2006, 89(2):5I7-529.

33. Wilson IG: Inhibition and facilitation of nucleic acid amplification. Appl Environ Microbiol 1997, 63(10):374I-375I.

34. Nelson K, Wang FS, Boyd EF, Selander RK: Size and sequence polymorphism in the isocitrate dehydrogenase kinase/phosphatase gene (aceK) and flanking regions in Salmonella enterica and Escherichia coli. Genetics 1997, 147(4): I509-1520.

35. Agron PG, Walker RL, Kinde H, Sawyer SJ, Hayes DC, Wollard J, Andersen GL: Identification by subtractive hybridization of sequences specific for Salmonella enterica serovar enteritidis. Appl Environ Microbiol 200I, 67( I I):4984-499I.

36. Thorns C): Bacterial food-borne zoonoses. Rev Sci Tech 2000 I 9(I):226-239.

37. Thorns CJ, Turcotte C, Gemmell CG, Woodward MJ: Studies into the role of the SEFI 4 fimbrial antigen in the pathogenesis of Salmonella enteritidis. Microb Pathog 1996, 20(4):235-246.

38. Schrank IS, Mores MA, Costa JL, Frazzon AP, Soncini R, Schrank A, Vainstein $\mathrm{MH}$, Silva SC: Influence of enrichment media and application of a PCR based method to detect Salmonella in poultry industry products and clinical samples. Vet Microbiol 200I, 82(I):45-53.

39. Lofstrom C, Knutsson R, Axelsson CE, Radstrom P: Rapid and specific detection of Salmonella spp. in animal feed samples by PCR after culture enrichment. Appl Environ Microbiol 2004, 70(I):69-75.

40. Beckers HJ, vd Heide J, Fenigsen-Narucka U, Peters R: Fate of salmonellas and competing flora in meat sample enrichments in buffered peptone water and in Muller-Kauffmann's tetrathionate medium. J Appl Bacteriol 1987, 62(2):97-104.

41. Hoorfar J, Cook N, Malorny B, Wagner M, De Medici D, Abdulmawjood A, Fach P: Diagnostic PCR: making internal amplification control mandatory. J Appl Microbiol 2004, 96(2):22I-222.

Publish with Bio Med Central and every scientist can read your work free of charge

"BioMed Central will be the most significant development for disseminating the results of biomedical research in our lifetime. "

Sir Paul Nurse, Cancer Research UK

Your research papers will be:

- available free of charge to the entire biomedical community

- peer reviewed and published immediately upon acceptance

- cited in PubMed and archived on PubMed Central

- yours - you keep the copyright

Submit your manuscript here:

http://www.biomedcentral.com/info/publishing_adv.asp
BioMedcentral 